\title{
OPIEKA PERSONELU PIELĘGNIARSKIEGO NAD DAWCA FRAGMENTU WĄTROBY
}

\author{
NURSING CARE OF A LIVER FRAGMENT DONOR
}

\author{
Marlena Szepietowska ${ }^{1}$, Marta Hreńczuk ${ }^{2}$ \\ ${ }^{1}$ Absolwentka studiów magisterskich \\ Warszawski Uniwersytet Medyczny \\ ${ }^{2}$ Zakład Pieleggniarstwa Chirurgicznego i Transplantacyjnego \\ Warszawski Uniwersytet Medyczny
}

DOI: https://doi.org/10.20883/pielpol.2017.28

\begin{abstract}
STRESZCZENIE
Wstęp. Przeszczepianie fragmentu wątroby od dawcy żywego jest jednym z wielkich osiągnięć medycyny XX wieku. Personel pielęgniarski bierze ważny udział w przygotowaniu dawcy do zabiegu pobrania fragmentu wątroby i opiece nad nim po zabiegu. Cel. Celem pracy była analiza opieki pielęgniarskiej sprawowanej wobec żywych dawców fragmentu wątroby, na podstawie oceny dokonanej przez nich samych.

Materiał i metoda. W badaniu wykorzystano kwestionariusz ankiety własnej konstrukcji, zawierający pytania dotyczące przestrzegania praw pacjenta oraz realizacji zadań z zakresu funkcji zawodowych przez pielęgniarki i ich postaw wobec dawców. Badaniu poddano 18 dawców w 3-7 dobie po zabiegu operacyjnym.

Wyniki. Dawcy byli zapoznawani z organizacją pracy oddziału, mieli zapewnioną higienę osobistą i otoczenia oraz dostarczone informacje odnośnie samoopieki. Wobec 4 dawców nie było przestrzegane prawo odmowy zgody na udzielanie świadczeń zdrowotnych realizowanych przez pielęgniarki.

Wnioski. Zgłaszane przez dawców braki w zakresie opieki dotyczyły rehabilitacji przyłóżkowej i udzielanego wsparcia oraz pomocy w zmniejszeniu lęku, jaki odczuwali podczas pobytu w szpitalu.
\end{abstract}

SŁOWA KLUCZOWE: dawca fragmentu wątroby, opieka pielęgniarska, prawa pacjenta, funkcje zawodowe.

\section{Wprowadzenie}

Przeszczepianie narządów to rutynowo stosowane zabiegi operacyjne ratujące życie. Rozwój transplantologii klinicznej w Polsce, poprzez zaangażowanie i wysiłek zespołów interdyscyplinarnych, pozwala osiągnąć wyniki leczenia odpowiadające światowym standardom. Przeszczepianie fragmentu wątroby od dawcy żywego, spokrewnionego lub niespokrewnionego, jest jednym z wielkich osiągnięć polskiej medycyny $\mathrm{XX}$ wieku, co ma wpływ na to, że temat ten jest ważny dla nauk o zdrowiu. Kluczową rolę w przygotowaniu dawcy do zabiegu oraz rekonwalescencji po nim odgrywa personel pielęgniarski, który jest odpowiedzialny za stwo-

\begin{abstract}
Introduction. Transplanting a liver fragment from a living donor is one of the greatest medical achievements of the 20th century. The nursing staff takes an important part in preparing the donor for liver surgery and taking care of the liver after surgery.

Aim. The aim of the study was to analyze nursing care given to living donors of a liver fragment based on their own evaluation. Material and methods. In the study a questionnaire survey of author's own design was used. It included questions about respecting patients' rights, performing occupational tasks by nurses and their attitudes towards donors. 18 donors were evaluated at 3-7 days after surgery.

Results. The donors were familiar with the work organization on the ward. Personal and environmental hygiene was provided to them, as well as the information on self-care. In case of four donors the law concerning the refusal to grant healthcare benefits by nurses was not respected.

Conclusions. The lack of care reported by donors involved bedside rehabilitation and support, as well as assistance in reducing anxiety during donors' stay in hospital.
\end{abstract}

KEYWORDS: liver fragment donor, nursing care, patient rights, occupational functions.

rzenie na oddziale szpitalnym warunków zgodnych z obowiązującymi standardami oraz sprawowanie profesjonalnej opieki opartej na aktualnych procedurach, które obejmują także przestrzeganie praw pacjenta. Zabieg pobrania fragmentu wątroby jest ingerencją w ciało zdrowego człowieka, zgodnie z literą prawa dopuszczony, obarczony jednak możliwością powikłań. Z tego też względu od całego zespołu medycznego wymaga się profesjonalizmu.

W Polsce przeszczepianie narządów od żywych dawców regulują Ustawa z dnia 1 lipca 2005 r. o pobieraniu, przechowywaniu i przeszczepianiu komórek, tkanek i narządów (z późniejszymi zmianami) oraz 
Dyrektywa Parlamentu Europejskiego i Rady Europy 2010/45/UE z dnia 7 lipca 2010 r. w sprawie norm jakości i bezpieczeństwa narządów ludzkich przeznaczonych do przeszczepienia. Przepisy prawa gwarantują żywemu dawcy jak najlepszą opiekę medyczną oraz psychologiczną. Dawcy ponoszą ryzyko śród- i pooperacyjne zabiegu pobrania fragmentu wątroby. Polskie prawo zapewnia ochronę dawcy, który musi podjąć samodzielną decyzję, na podstawie wszystkich znaczących informacji na temat celu, charakteru, konsekwencji i ryzyka dawstwa, o których jest informowany z wyprzedzeniem. Żywy dawca jest zapewniony o dobrowolnym i nieodpłatnym dawstwie narządu. Dawstwo od żywych dawców powinno minimalizować ryzyko fizyczne, psychologiczne i społeczne dla dawcy oraz biorcy, a także nie zagrażać zaufaniu publicznemu do państwowego systemu ochrony zdrowia [1, 2].

Żywe dawstwo wątroby polega na pobraniu fragmentu narządu, najczęściej od rodzica dla chorego dziecka. W Polsce pierwszy zabieg pobrania segmentów wątroby celem transplantacji przeprowadzono w 1999 roku w Klinice Chirurgii Ogólnej, Transplantacyjnej i Wątroby Akademii Medycznej w Warszawie. Dawcą był ojciec, a biorcą jego czteroletnia córka, której wszczepienie narządu przeprowadzono w Centrum Zdrowia Dziecka w Warszawie. Do dzisiaj są to jedyne w Polsce ośrodki wykonujące taką procedurę transplantacyjną [3-5].

Przeszczepianie fragmentu wątroby od żywych dawców budzi społeczne oraz etyczne wątpliwości ze względu na ryzyko powikłań śród- i pooperacyjnych, a nawet zgonu, jakim obarczony zostaje dawca, osoba w pełni zdrowa. Za takimi zabiegami przemawia fakt braku narządów od zmarłych dawców pediatrycznych, natomiast wskaźnik śmiertelności dzieci z wadami rozwojowymi wątroby oraz dróg żółciowych, które stanowią wskazania do transplantacji wątroby, jest bardzo wysoki, a w stanie zagrożenia życia biorcy zabieg ten jest jedyną skuteczną metodą ratowania tych dzieci $[5,6]$. Z danych prezentowanych przez Królikowską i Spieszko wynika, że od roku 1999 w ciągu 10 lat przeszczepienia rodzinne wykonywane były w Polsce regularnie, 2-3 razy w miesiącu. Biorcy byli w wieku od 1 miesiąca do 11 lat. W większości przypadków dawcami były matki, a następnie ojcowie dzieci [7]. Według danych Centrum Organizacyjno-Koordynacyjnego ds. Transplantacji „PoItransplant” od stycznia 2008 roku do końca kwietnia 2015 roku wykonano 150 zabiegów przeszczepienia fragmentu wątroby od dawcy żywego. Średnio jest to 20 pobrań fragmentów wątroby w ciągu roku. Najwięcej transplantacji z takiego pobrania odbyło się w roku 2014 - aż 30 [8, 9].

Perspektywa pobrania fragmentu wątroby od żywego dawcy jest uwarunkowana, przede wszystkim wzglę- dami medycznymi, ale podobnie ważną rolę odgrywają aspekty środowiskowe, socjalne, kulturowe i psychiczne. Odsetek dyskwalifikacji dawców z tych powodów, według danych z wielu ośrodków światowych, sięga 70 $-80 \%$ [10].

Kwalifikacja potencjalnego żywego dawcy fragmentu wątroby jest procesem etapowym, w którym na początku najważniejsza jest deklaracja potencjalnego dawcy chęci dobrowolnego oddania fragmentu wątroby i świadomego poddania się operacji. Decyzja dawcy powinna być przemyślana, podjęta bez nacisków ze strony rodziny czy zespołu leczącego. Na każdym etapie ewentualne zastrzeżenia, wątpliwości czy trudności diagnostyczne powinny być rozstrzygane tak, byzachować priorytetbezpieczeństwa dawcy. Okres kwalifikacji jest rozciągnięty w czasie i składa się z czterech etapów, które obejmują wstępną ocenę dawcy, badania psychologiczne, laboratoryjne, obrazowe, niekiedy inwazyjne, a kończą się opinią komisji zespołu transplantologów, którzy ostatecznie podejmują decyzję o zabiegu, określając pilność transplantacji w zależności od stopnia niewydolności wątroby biorcy [10, 11]. Przy braku jakichkolwiek przeciwwskazań zwieńczeniem tych działań jest zabieg pobrania i przeszczepienia fragmentu wątroby. Na każdym z tych etapów ważną rolę odgrywa zespół pielęgniarski, który powinien cechować się profesjonalizmem, znajomością praw pacjenta i ich przestrzeganiem, postawą niesienia pomocy na każdym etapie opieki i empatią.

Pobranie fragmentu wątroby jest zabiegiem chirurgicznym wykonywanym w znieczuleniu ogólnym, dawca wymaga przygotowania zarówno psychicznego, jak i fizycznego. Po zabiegu operacyjnym charakteryzuje się on obecnością rany operacyjnej, drenu wyprowadzonego z jamy brzusznej, towarzyszą mu dolegliwości bólowe, ograniczenie ruchowe, deficyt samopielęgnacji, zachodzi konieczność dożylnego podawania leków i płynów. Jak w sytuacji każdego pacjenta chirurgicznego konieczna jest profilaktyka i wczesne rozpoznanie powikłań pooperacyjnych, w tym wczesne uruchamianie, gimnastyka oddechowa i edukacja. Dawcy chcą szybko wrócić do sprawności ruchowej sprzed zabiegu operacyjnego, by móc opiekować się biorcą, któremu oddali fragment narządu. Dlatego też należy szczególnie podkreślić rolę personelu pielęgniarskiego w rekonwalescencji dawcy podczas jego pobytu w szpitalu, z uwzględnieniem różnych funkcji zawodowych, takich jak: opiekuńcza, wychowawcza, profilaktyczna i rehabilitacyjna.

\section{Cel pracy}

Celem pracy była analiza opieki pielęgniarskiej sprawowanej wobec żywych dawców fragmentu wątroby, na podstawie oceny dokonanej przez nich samych. 
Postawiono następujące pytania badawcze:

1. Czy w momencie przyjęcia pielęgniarki zapoznawały pacjenta z organizacją pracy oddziału?

2. Czy personel pielęgniarski przestrzegał praw pacjenta w opiece nad dawcą?

3. W jakim zakresie personel pielęgniarski pomagał pacjentowi w czynnościach higieniczno-pielęgnacyjnych po zabiegu operacyjnym?

4. Jaką postawą wykazywał się personel pielęgniarski wobec pacjenta podczas pobytu w szpitalu?

5. Czy pielęgniarki w ramach edukacji zdrowotnej udzieliły wystarczających informacji odnośnie samoopieki po wyjściu dawcy ze szpitala?

\section{Metoda i materiał}

Badania prowadzono od czerwca 2014 do kwietnia 2015 roku i objęto nimi 18 dawców fragmentu wątroby spośród 23 przebywających w tym czasie w klinice 4 pacjentów nie wyraziło zgody na udział w badaniu argumentując, iż jest to dla nich trudna sytuacja życiowa i czują psychiczny dyskomfort, natomiast jeden pacjent nie wziął udziału ze względu na barierę językową (obcokrajowiec). Badanie zostało przeprowadzone za pomocą kwestionariusza ankiety własnego autorstwa, który zawierał 33 pytania, w tym metryczkę charakteryzującą płeć, wiek, dobę po zabiegu operacyjnym i miejsce zamieszkania dawcy oraz odnoszące się do opieki okresu okołooperacyjnego. Formułując pytania do kwestionariusza ankiety starano się prześledzić opiekę pielęgniarską od momentu przyjęcia dawcy celem zabiegu operacyjnego do czasu wypisania go do domu, uwzględniając funkcje zawodowe pielęgniarki (14 pytań), wybrane prawa pacjenta (8 pytań) oraz postawę pielęgniarki względem dawcy (7 pytań). Udział w badaniu był dobrowolny, a ankieta anonimowa. Komisja Bioetyczna przy Warszawskim Uniwersytecie Medycznym nie zgłosiła zastrzeżeń do badania. Na jego przeprowadzenie wyraził zgodę kierownik Katedry i Kliniki Chirurgii Ogólnej, Transplantacyjnej i Wątroby WUM, na terenie której przebywali pacjenci.

W celu opracowania wyników użyto arkusza kalkulacyjnego Microsoft Office Excel, do utworzenia bazy danych wykorzystano oprogramowanie SPSS for Windows.

W badaniach wzięło udział 11 kobiet oraz 7 mężczyzn. Najwięcej badanych było w przedziale wiekowym 30-39 lat ( $\mathrm{N}=11)$. Wśród kobiet średnia wieku wynosiła 31 lat $(S D=2,48)$, najmłodsza kobieta miała 28 lat, najstarsza 46 lat. Średnia wieku mężczyzn wyniosła 32 lata $(S D=2,29)$, najmłodszy mężczyzna miał 26 lat, najstarszy 41 lat. $W$ badanej grupie 10 pacjentów mieszkało w mieście, 8 mieszkało na wsi. W 6 dobie po zabiegu ankietę wypełniło 9 pacjentów, w dobie 3, 4 i 7 po 3 osoby.

\section{Wyniki}

Pierwsze pytania kierowane do pacjentów dotyczyły realizacji zadań, jakie należą do pielęgniarki podczas przyjęcia do oddziału. Szesnastu ankietowanych zostało zapoznanych z topografią oddziału, 15 uzyskało informacje o regulaminie oraz organizacji oddziału, 14 zostało poinformowanych o prawach wynikających z Karty Praw Pacjent (Rycina 1).

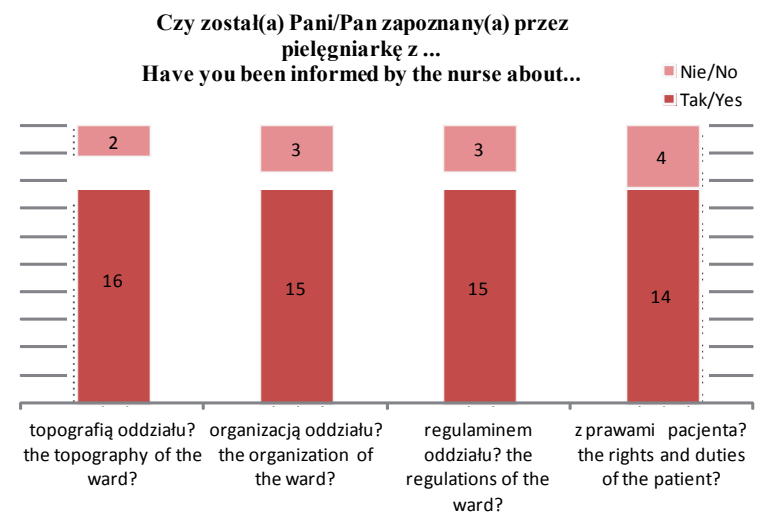

Rycina 1. Informacje przekazywane przez personel pielęgniarski przy przyjęciu do oddziału

Figure1. The information provided by the nursing staff on admission to the ward

Źródło: opracowanie własne

Source: author's own analysis

W opinii 18 pacjentów personel pielęgniarski przestrzegał 7 spośród 8 wskazanych w ankiecie praw pacjenta, 4 badanych stwierdziło, że nie było respektowane wobec nich prawo odmowy zgody na udzielanie świadczeń zdrowotnych realizowanych przez pielęgniarki (Rycina 2).

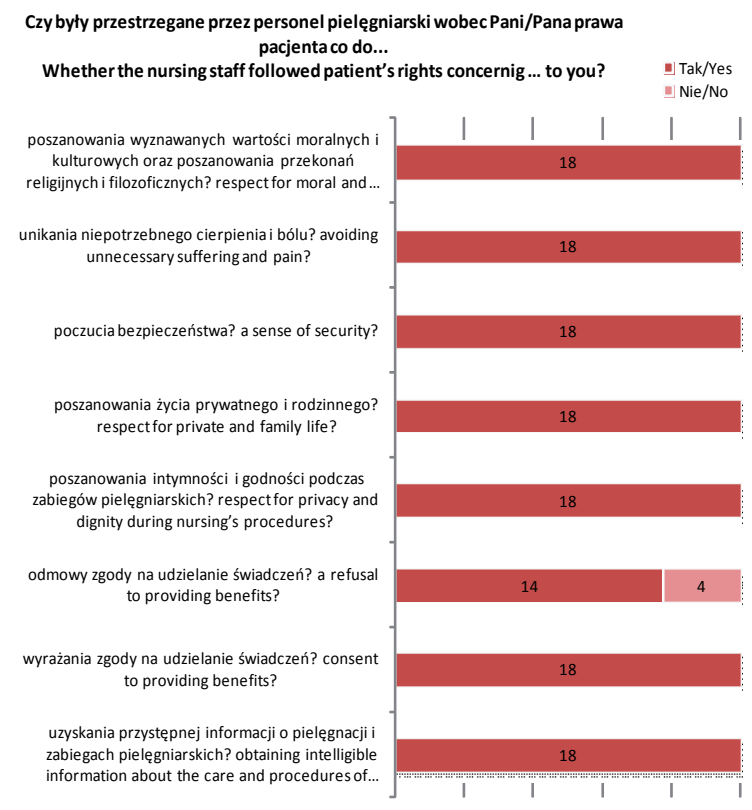

Rycina 2. Przestrzeganie wybranych praw pacjenta przez personel pielęgniarski

Figure 2. Compliance with selected patient rights by the nursing staff Źródło: opracowanie własne Source: author's own analysis 
Pacjenci oceniali realizację bezpośrednich funkcji zawodowych personelu pielęgniarskiego wobec nich samych, takich jak funkcja opiekuńcza, wychowawcza, profilaktyczna i rehabilitacyjna. Personel pielęgniarski udzielał potrzebnej pomocy pacjentom w czynnościach higieniczno-pielęgnacyjnych i rehabilitacyjnych w różnym zakresie (Rycina 3). Pomoc ta dotyczyła higieny osobistej, higieny otoczenia (pościel, stolik przyłóżkowy), pomocy w spożywaniu posiłków oraz przy zmianie pozycji w łóżku. W zakresie rehabilitacji przyłóżkowej pomocy potrzebowało 8 dawców, spośród których nie wszyscy taką pomoc otrzymali $(\mathrm{N}=2)$. Dziewięciu ankietowanych, którzy potrzebowali pomocy w przemieszczaniu się do toalety i z powrotem, na taką pomoc mogło liczyć czasami, tylko 2 badanych zawsze.

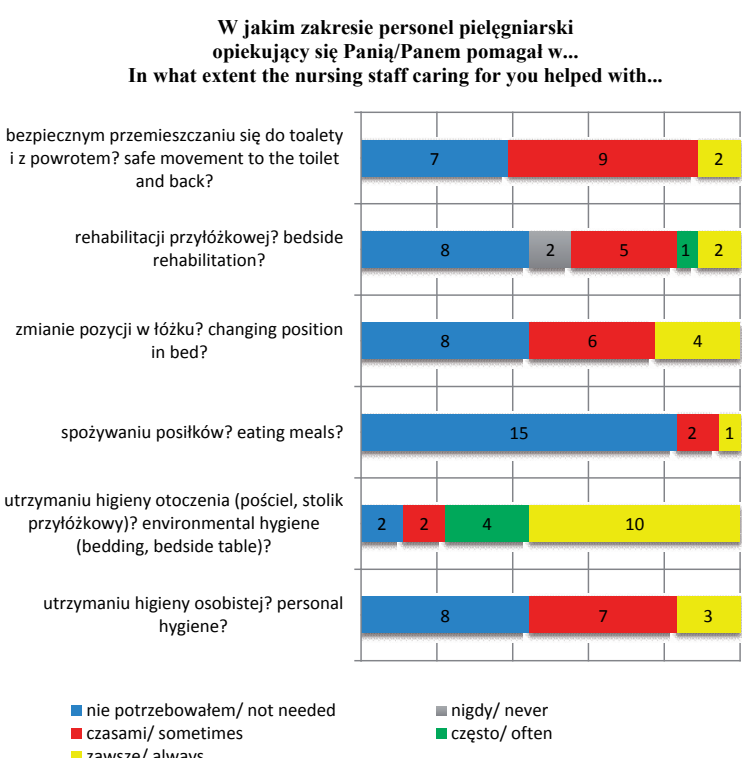

Rycina 3. Pomoc personelu pielęgniarskiego w czynnościach higieniczno-pielęgnacyjnych i rehabilitacyjnych

Figure 3. Help the nursing staff in the activities of hygienic care and rehabilitation

Źródło: opracowanie własne

Source: author's own analysis

Zapytano dawców o ocenę częstotliwości podejmowanych przez pielęgniarki zachowań wspierających w trakcie pobytu w szpitalu. Jeden spośród 18 badanych pacjentów wskazywał, że personel pielęgniarski nie potrafi udzielić wsparcia, wysłuchać, zmniejszyć lęku, 1 badany wskazał, że pielęgniarki czasami przygotowywały do badań diagnostycznych w aspekcie fizycznym i psychicznym. Zdaniem 15 pacjentów personel pielęgniarski zawsze szybko i sprawnie reagował na wezwanie (dzwonek) oraz prośby, w opinii 17 pacjentów personel mobilizował dawców do działań umożliwiających jak najszybsze osiągnięcie samodzielności i powrót do formy po zabiegu operacyjnym, według 12 dawców zawsze poświęcał im wystarczającą ilość czasu (Rycina 4).

Celem określenia funkcji wychowawczej sprawowanej przez pielęgniarki zapytano ankietowanych o aspekt edukacji zdrowotnej przed wypisem ze szpitala. Wszyscy byli zgodni, że personel pielęgniarski udzielił wystarczających informacji odnośnie samoopieki po wyjściu ze szpitala we wszystkich ważnych aspektach odnoszących się do diety, pielęgnacji rany operacyjnej, wizyt kontrolnych oraz wysiłku fizycznego.

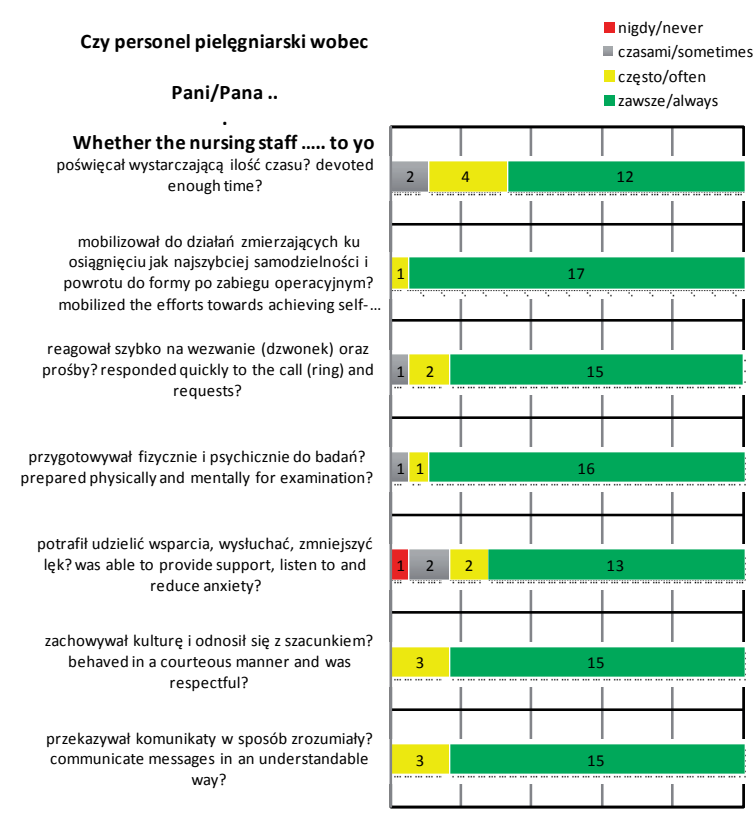

Rycina 4. Postawa personelu pielęgniarskiego wobec dawców fragmentu wątroby

Figure 4. The attitude of the nursing staff to a portion of liver donors

\section{Dyskusja}

Zabiegi transplantacji fragmentu wątroby wykonywane są u biorców pediatrycznych. W 2014 roku w Polsce było 30 pobrań fragmentu wątroby celem przeszczepienia [9]. Zarówno pobranie fragmentu wątroby, jak i zabieg transplantacji są procedurami wysokospecjalistycznymi, wymagającymi od zespołów interdyscyplinarnych wiedzy i umiejętności na każdym etapie opieki oraz dużego zaangażowania i wzajemnej współpracy. Udział pielęgniarki w opiece nad żywym dawcą fragmentu wątroby to $\mathrm{m}$.in. pomoc w przygotowaniu do badań diagnostycznych, do samego zabiegu operacyjnego, opieka po zabiegu i edukacja zdrowotna. Jak wykazały badania, w opinii samych dawców nie tylko samo przygotowanie fizyczne do zabiegu operacyjnego ma istotne znaczenie w osiągnięciu dobrostanu, zwracają oni uwagę na kwestię wsparcia, pomocy w zmniejszeniu lęku, konieczność częstszej obecności personelu pielęgniarskiego 
przy ich łóżku. Dawcy wskazywali na braki w zakresie takiego wsparcia, co wynikać może właśnie ze zwiększonego zapotrzebowania na taką pomoc w sytuacji, w jakiej się znaleźli. Czas oczekiwania na zabieg operacyjny stanowi dla każdego hospitalizowanego pacjenta sytuację trudną. W grupie dawców trudną z dwóch powodów, z jednej strony operowani są oni sami, z drugiej bliska im osoba, najczęściej własne dziecko. Leczenie chirurgiczne pociąga za sobą wyjątkowo duże obciążenie emocjonalne chorego, obfitując w okoliczności zagrażające i budzące lęk. Wyniki badań empirycznych już od lat osiemdziesiątych pozwalają stwierdzić, że w obrazie reakcji emocjonalnych człowieka oczekującego na operację lęk wysuwa się na plan pierwszy [12-15]. Udzielane w tym niezwykle ważnym dla chorego okresie wsparcie powinno skutecznie neutralizować niepożądane, negatywne emocje. Przyjazna atmosfera, szacunek, wykazanie zrozumienia, poświęcanie dawcy większej ilości czasu może skutecznie zminimalizować lęk i towarzyszący stres. W doniesieniach psychologicznych wymienia się cztery rodzaje wsparcia społecznego: emocjonalne, informacyjne, wartościujące oraz instrumentalne [15], z których może korzystać pielęgniarka sprawująca opiekę nad pacjentem chirurgicznym. W sytuacji trudnej ważną grupą wsparcia jest rodzina, przyjaciele, sąsiedzi, organizacje zarówno o charakterze formalnym, jak i nieformalnym, medycy (lekarz, pielęgniarka), nauczyciele, duchowni, grupy samopomocy [15-18]. Współczesne pielęgniarki, posiadające przygotowanie merytoryczne na poziomie akademickim, są dobrze przygotowane do pełnienia wielu ważnych funkcji i ról zawodowych w opiece nad chorym, w tym - jakże ważnej dla każdego pacjenta, roli wspierającej i edukacyjnej. Rola pielęgniarki w tym zakresie jest o tyle istotna, że jest ona tym z członków zespołu interdyscyplinarnego, sprawującego opiekę nad dawcą, z którym pacjent ma najczęstszy kontakt.

W momencie przyjęcia dawcy na oddział staje się on pacjentem, któremu personel medyczny udziela wszelkich świadczeń zdrowotnych, respektując prawa pacjenta. Pielęgniarka udziela pacjentowi świadczeń zapobiegawczych, diagnostycznych, leczniczych, rehabilitacyjnych i edukacyjnych. Troszczyć się powinna o jego sferę fizyczną, psychiczną i społeczną przez cały pobyt w szpitalu $[19,20]$. Wybrane przez autorów prawa pacjenta były respektowane przez personel pielęgniarski w zdecydowanej większości. Niepokój budzi jednak fakt braku respektowania wobec 4 dawców przez pielęgniarki prawa pacjenta do odmowy zgody na udzielanie świadczeń zdrowotnych. Być może wynika to z tego, że pielęgniarki, postępując zgodnie z procedurami, nie pytały przed każdą czynnością o zgodę pacjenta na jej wykonanie. Zgodnie z obowiązującym prawem każdo- razowo należy uzyskać zgodę na świadczenia zdrowotne wykonywane przez personel pielęgniarski i wziąć pod uwagę możliwość odmowy, która powinna być udokumentowana [19, 20]. Zgodnie z Ustawą o zawodach pielęgniarki i położnej [Dz.U. 2011 nr 174 poz.1039] oraz Rozporządzeniem Ministra Zdrowia w sprawie rodzaju i zakresu świadczeń zapobiegawczych, diagnostycznych, leczniczych i rehabilitacyjnych udzielanych przez pielęgniarkę albo położną samodzielnie bez zlecenia lekarskiego [Dz.U.07.210.1540] pielęgniarka uprawniona jest do wykonywania zabiegów pielęgnacyjnych oraz wybranych świadczeń leczniczych, prowadzenia poradnictwa w zakresie samoopieki oraz rehabilitacji przyłóżkowej, jednak ważne jest uzyskanie zgody pacjenta na podejmowane działania.

W wielu czynnościach higieniczno-pielęgnacyjnych po zabiegu operacyjnym pacjenci nie potrzebowali pomocy personelu pielęgniarskiego. W pierwszej dobie po zabiegu chory wymaga intensywnego nadzoru, dlatego też jest umieszczony na oddziale, gdzie taki nadzór jest możliwy. Samodzielność chorego i zdolność do samopielęgnacji jest ograniczona z powodu rany operacyjnej, obecności drenu, bólu, dlatego w tym wczesnym czasie po zabiegu nieodzowna wydaje się pomoc personelu w codziennych czynnościach [23, 24]. Ważnym aspektem jest wczesne uruchamianie pacjenta (jako profilaktyka powikłań związanych z unieruchomieniem) oraz wczesny powrót dawcy do normalnego funkcjonowania. Takie działania powinny już być podejmowane następnego dnia po zabiegu, a ich zakres powinien obejmować, poczynając od zmiany pozycji w łóżku, ćwiczenia bierne, czynne, do pionizacji i uruchomienia poza salą chorych. W badanej grupie znalazły się 2 osoby, którym nigdy nie pomagano w rehabilitacji przyłóżkowej. Kompetencje związane z prowadzeniem rehabilitacji medycznej po zabiegu operacyjnym na danym oddziale należą do rehabilitantów. Jednak pielęgniarki mają obowiązek prowadzić rehabilitację przyłóżkową, pomagać w usprawnianiu ruchowym pacjentów [21, 22]. Działania takie mają znaczenie w profilaktyce powikłań pooperacyjnych wynikających z unieruchomienia pacjenta. Być może pielęgniarki ze względu na obszerny zakres czynności leczniczych i diagnostycznych wykonywanych przy pacjentach mniejszą uwagę przywiązywały do prowadzenia rehabilitacji przyłóżkowej dawców. Najwięcej ankietowanych zwróciło uwagę, iż personel pielęgniarski zawsze dbał o utrzymanie higieny otaczającego ich środowiska.

\section{Wnioski}

1. Dawcy fragmentu wątroby podczas przyjęcia na oddział uzyskiwali informacje dotyczące to- 
pografii, organizacji i regulaminu oddziału, pomijano przedstawienie pacjentowi Karty Praw Pacjenta.

2. W ocenie dawców nie wszystkie ich prawa jako pacjentów były przestrzegane. W praktyce należy zwrócić większą uwagę na respektowanie prawa do wyrażenia lub nie wyrażenia zgody na udzielanie świadczeń zdrowotnych wykonywanych przez pielęgniarki.

3. Zgłaszane przez dawców braki w zakresie opieki pooperacyjnej dotyczyły rehabilitacji przyłóżkowej.

4. Personel pielęgniarski nie zawsze udzielał oczekiwanego wsparcia biorcy oraz pomocy w zmniejszeniu lęku odczuwanego podczas pobytu w szpitalu. W realizacji opieki nad dawcą należy zwrócić większą uwagę na takie działania.

5. W opinii pacjentów edukacja zdrowotna realizowana przez pielęgniarki jest wystarczająca.

\section{Piśmiennictwo}

1. Ustawa z dnia 1 lipca 2005 r. o pobieraniu, przechowywaniu i przeszczepianiu komórek, tkanek i narządów /Dz. U. 2005 nr 169 poz. 1411/.

2. Dyrektywa Parlamentu Europejskiego i Rady 2010/45/UE z dnia 7 lipca 2010 r. w sprawie norm jakości i bezpieczeństwa narządów ludzkich przeznaczonych do przeszczepienia.

3. Kaliciński P. Przeszczepienie wątroby od żywego dawcy. Służ Zdr 2000;3:4-6.

4. Krawczyk M. Historia przeszczepiania od żywego dawcy. W: Krawczyk M, Patkowski W. (red.). Przeszczepianie wątroby od żywego dawcy. Lublin: Wyd. Czelej; 2008. 1-3.

5. Kaliciński P. Przeszczepianie części wątroby od żywych dawców u dzieci. W: Krawczyk M, Patkowski W. (red.). Przeszczepianie wątroby od żywego dawcy. Lublin: Wyd. Czelej; 2008. 85-92.

6. Wałaszewski J, Stryjecka-Rowińska D. Żywy dawca narządów. W: Rowiński W, Wałaszewski J, Pączek L. (red.). Transplantologia kliniczna. Warszawa: PZWL; 2004. 47-49.

7. Królikowska U, Spieszko G.M. Przeszczepy rodzinne jako nowoczesna metoda leczenia niewydolności wątroby u dzieci - rola pielęgniarki w procesie leczenia. Prz Chir Dziec 2009; 4 (2-3): 94-96.

8. Antoszkiewicz K, Czerwiński J. Pobieranie i przeszczepianie narządów w Polsce w 2014 r. Biul Poltransplantu 2015:25-40.

9. Czerwiński J, Malanowski P. Przeszczepianie narządów w Polsce 1966-2014. Biul Poltransplantu 2015:41-43.

10. Czerwinski J, Małkowski P. Pielęgniarstwo transplantacyjne. Poznań: Ars Nova; 2014. 249-252.

11. Ohler L, Cupples S. Core curriculum for transplant nurses. St. Louis, Missuri, Mosby Elsevier 2008. 267-286.

12. Modzelewska M, Wołowicka L, Admiraal P. Dynamika lęku okołooperacyjnego. Przegl. Psychol. 1985; 24:1103-1110.

13. Niechwiadowicz-Czapka T. Rola i zadania pielęgniarki w zakresie przygotowania psychicznego pacjenta do operacji. Puls Uczelni. 2014;8,2:36-44.
14. Heszen-Niejodek I. Problemy psychologiczne i zadania psychologa w chirurgii. W: Heszen-Niejodek I. Rola psychologa w diagnostyce i leczeniu chorób somatycznych. Warszawa: PZWL; 1990. 120-130.

15. Szutarska A, Andruszkiewicz A. Czynniki wyznaczające stan psychiczny i wpływające na ocenę opieki pielęgniarskiej. Pielęg Chir Angiol 2010; 1: 1-5.

16. Kmiecik-Baran K. Skala Wsparcia Społecznego. Teorie i właściwości psychometryczne, Przegl Psychol 1995;38:201-214.

17. Dyga-Konarska M. Informacyjne i emocjonalne wsparcie pacjenta przez personel medyczny. Stand Med 2004; 5:599-604.

18. Zielińska-Więczkowska H, Pryka K, Muszalik M. i wsp. Wsparcie w opiece pielęgniarskiej pacjentów w podeszłym wieku przed zabiegiem operacyjnym - na tle czynników socjo-demograficznych. Psychogeriatria Pol 2012;9(2):61-68.

19. Ustawa z dnia 6 listopada 2008 r. o prawach pacjenta i Rzeczniku Praw Pacjenta /Dz.U. 2009 nr 52 poz. 417/.

20. Przepisy prawne - Instytut Praw Pacjenta i Edukacji Zdrowotnej http://www.prawapacjenta.eu/, (data dostępu 201503-24).

21. Ustawa z dnia 15 lipca 2011 r. o zawodach pielęgniarki i położnej /Dz. U. 2011 nr 174 poz. 1039/.

22. Rozporządzenie Ministra Zdrowia z dnia 7 listopada 2007 r. w sprawie rodzaju i zakresu świadczeń zapobiegawczych, diagnostycznych, leczniczych i rehabilitacyjnych udzielanych przez pielęgniarkę albo położną samodzielnie bez zlecenia lekarskiego /Dz.U.2007 nr 210 poz.1540/.

23. Candido HL, da Fonseca EA, Feier FH. Risk Factors Associated with Increased Morbidity in Living Liver Donation. J.Transplant. 2015;10:9474-96.

24. Cuppies S, Ohler L. Transplantation Nursing Secrets. Hanley \& Belfus, Philadelphia: 2003. 213-226.

\section{Podziękowania}

Autorzy składają serdeczne podziękowania Panu prof. dr hab. n. med. Markowi Krawczykowi, kierownikowi Kliniki Chirurgii Ogólnej, Transplantacyjnej i Wątroby Samodzielnego Publicznego Centralnego Szpitala Klinicznego w Warszawie, za umożliwienie przeprowadzenia badań w klinice. Serdeczne wyrazy wdzięczności kierują również do Pielęgniarki Koordynującej w/w kliniki Pani Barbary Pawłowskiej za życzliwość i okazaną pomoc w trakcie pozyskiwania materiału do napisania tej pracy.

Artykuł przyjęty do redakcji: 15.02 .2016

Artykuł przyjęty do publikacji: 17.08.2016

Źródło finansowania: Praca nie jest finansowana z żadnego źródła. Konflikt interesów: Autorzy deklarują brak konfliktu interesów.
Adres do korespondencji:
Marta Hreńczuk
ul. Oczki 6
02- 005 Warszawa
Tel. 225021920
e-mail: mart.hrenczuk@wum.edu.pl
Zakład Pielęgniarstwa Chirurgicznego i Transplantacyjnego
Warszawski Uniwersytet Medyczny 